\title{
Evaluation of the status of ethical leadership among educational managers of Kurdistan University of Medical sciences from the viewpoint of managers and faculty members
}

Ghaderi M., PhD ${ }^{1}$, Karimian M., MSc ${ }^{2}$, Moballeghi j., MD $^{3}$

1. Associate Professor, Allameh Tabataba'i University, Tehran, Iran (Corresponding Author), Tel:+98-87-44737510, m.ghaderi@atu.ac.ir

2. Master of Art, Educational Management at the Electronic Branch, Islamic Azad University, Tehran, Iran.

3. Associate Professor, Surgery Department, Kurdistan University of Medical Sciences, Sanandaj, Iran .

\begin{abstract}
Background and Aim: One of the most important characteristics of a leader is the ability to understand the ethical concepts and standards of management. The aim of this study was to evaluate the status of ethical leadership among the educational managers in Kurdistan University of Medical Sciences.

Material and Method: In this descriptive-analytical study, we evaluated the viewpoints of 92 faculty members and 26 directors of educational departments and educational deputies of hospitals and schools by using two standard questionnaires. Using SPSS Ver.19 software, data were analyzed by chi-square and t-tests.

Results: The results related to the ethical leadership domains from the viewpoints of the participants in this study (faculty members and educational staff) showed that $69.28 \%, 69.8 \%$ and $73.98 \%$ of the managers respected ethical principles, ethics in decision making and ethical behavior, respectively. There was a significant relationship between academic level and ethics in decision making ( $\mathrm{p}<0.005)$. Also, $71.54 \%$ of educational managers believed that they have demanded justice in their decision-making.

Conclusion: The results of this study suggested that although the status of the university is relatively appropriate in the domains of ethical management, but its effect on labor productivity and other communication variables is not clear. Therefore, further studies on this subject are recommended.
\end{abstract}

Keywords: Ethical leadership, Educational managers, Faculty.

Received: Apr 22, 2017 Accepted: Apr 9, 2018 


\title{
بررسى وضعيت رهبرى اخلاقى در ميان مديران آموزشى دانشكاه علوم بزشكى كردستان از

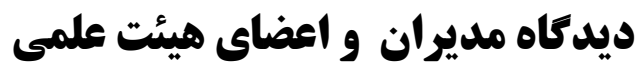

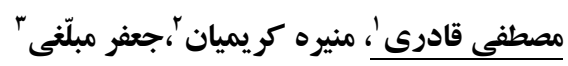

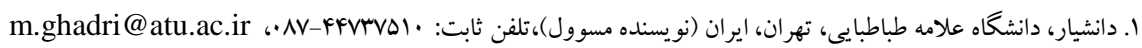

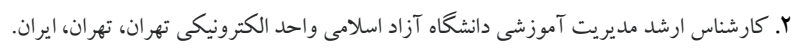

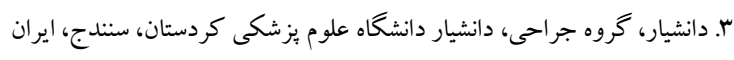

جكکيده

مقدمه: يكى از مهم ترين وظائف يكك رهبر برخوردارى از قدرت فهم مفاهيم و موازين اخلاقى مديريت است. هدف از اين

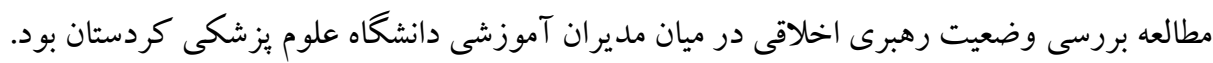

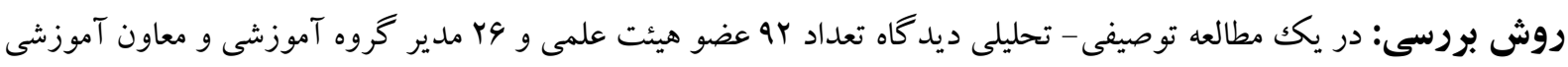

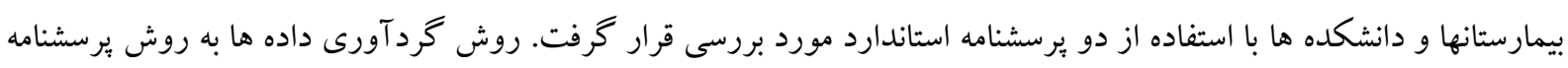

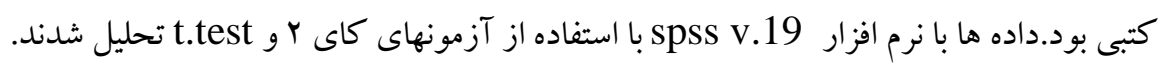

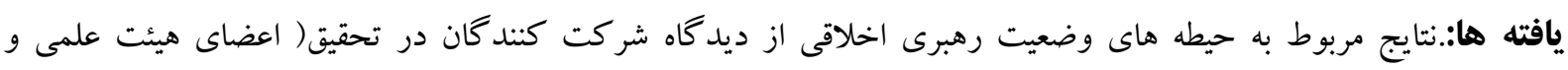

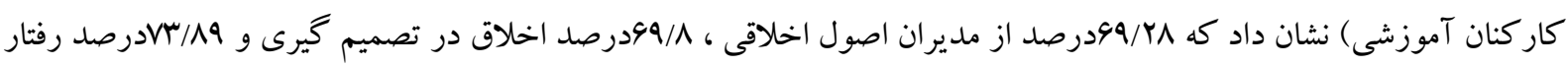

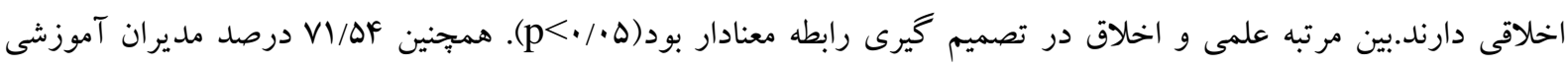
معتقد بودند در تصميم گيريها عدالت رار رعايت ميكنند. نتيجه كيرى: نتايج مطالعه حاضر نشان داد هرجند در حيطه هاى مديريت اخلاقى وضعيت دانشكاه نسبتا مناسب است، ولى ولى تاثير اين وضعيت بر راندمان كارى و ساير متغيرهاى ارتباطى مشخص نيست كه انجام مطالعات بيشترى در اين راستا توصيه ميشود.

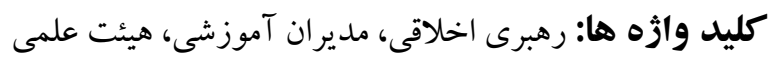

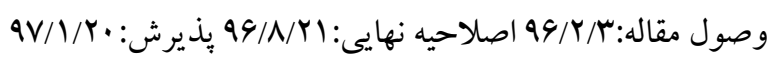


دخالت دهد. همبِنين رهبرى اخلاقى قادر است تا از طريق

فرآيند الكوبردارى بر كاركنان خود در تمام سطوح

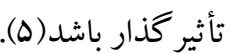
بيشتر محقّقانى كه به بررسى رهبرى اخلاقى بيرداخته اند بر ويز گى هاى رهبرى و نتايج وابسته به آن تمركز دارند، اهميّت اين موضوع از آن جهت است كه تصميماتى كه يكك رهبر اخلاقى در سازمان و محيط كار خود اتخاذ مى كند، يِامد هايى را هم براى خود او و هم براى سازمان و كاركنانش دارد. بنابراين بررسى متغيّرهايى كه بر تصميم

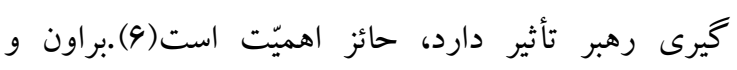
تروينو (V) اظهار داشته اند؛ يزوهش ها در حوزه ى رهبرى اخلاقى نسبتاً جديد است اما على رغم جديد بودن آن موضوعى است كه يتانسيل زيادى براى محقّقان دانشخاهى دربر دارد. سازمان هاى آموزشى و دانشگاه ها نيز مى خواهند بدانند جِكونه به بهترين شكل به دانشجويان آموزش دهند تا در آينده تبديل به رهبران اخلاقى شوند(Y). رهبرى اخلاقى مديران داراى هفت مؤلفه است و عبارتند از: جهت گيرى مردمى، عدالت، تسهيم قدرت، ثبات سازمانى، رهنمودهاى اخلاقى، وضوح نقش و صداقت و جهار مؤلفه مربوط به اعضاء هيأت علمى شامل اصول اخلاقى روشن و كويا، جوّ اخلاقى، اخلاق در تصميم گيرى و رفتار اخلاقى مى باشند. با توجّه به اهميّت رهبرى اخلاقى در سازمان ها، تحقيقات محدودى در سطح كشور و خارج انجام شده است. از جمله عمادى فر(^)، با انجام بثزوهشى تحت عنوان بررسى سبك رهبرى اخلاقى از ديدكاه اساتيد دانشگاه فردوسى مشهد و رابطهى آن با توانمند سازى آنان، به اين نتيجه رسيد كه نمره ى سبك رهبرى اخلاقى مديران جامعه مورد نظر با متوسط نمره شركت كنند گان تقريباً برابر است. همجِنين بررسى وضعيّت توانمندسازى كاركنان رابطه مثبت و معنى دارى با سبكك رهبرى اخلاقى مديران دارد. در مطالعه اي ديخر الوانى و همكاران(9)، در تحقيقى با عنوان تحليل اخلاقى سازمانى كاركنان با استفاده از الكوى دايره اخلاق، به اين نتيجه رسيدند كه گرايش كار كنان دانشخاه به
موفقيت سازمان ها در تأمين هدف ها و انجام دادن مسئوليّت هاى اجتماعى، تا حدود زيادى به مديران و عملكرد آنان بستخى دارد. زيرا اين مديران هستند كه از طريق ايجاد

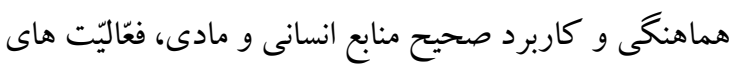
سازمان و افراد سازمانى را جهت تحقّق اهداف مورد نظر، هدايت و راهبرى مى كنند.فر آيند رهبرى و مديريت اثرى مستقيم بر توانايى هاى آموزشى، يُوهشى و بالطّبع درمانى در دانشگاه هاى علوم بزشكى كشور در ايجاد جوّ مطلوب سازمانى و نهايتاً موفقيت آنها دارد.موضوع رهبرى و نظريه هاى آن در قلمرو سازمان و مديريت از مباحث مهم در رفتار سازمانى و روابط انسانى است(1). يكى از مهم ترين وظائف يكك رهبر برخوردارى از قدرت فهم مفاهيم و موازين اخلاقى مديريت است. از طرف ديخر با توجّه به افزايش معضلات اخلاقى در سازمان ها و مشكلاتى كه در روابط مديران يا كارمندان به ويزه در سازمان هاى آموزشى وجود دارد مسئله رهبرى اخلاقى به يكك مسئله بسيار مهم تبديل شده كه مورد توجّه صاحبنظران از جمله دانشگاهيان، مديران و سياستخذاران قرار كرفته است (Y). تكيه بر مسند رهبرى اخلاقى و مديريت يكك سازمان به ويزه سازمان آموزشى و موفقيّت در انجام وظائف مربوط به آن سازمان مستلزم داشتن سه قابليّت تحت عنوان: دانش يا تخصّص، مهارت يا تجربه و بينش و مسئوليّت اخلاقى است. بنابراين، مدير و رهبر يكك سازمان آموزشى بايد با بهره كيرى از صلاحديد و بصيرت كه يك مقوله اخلاقى است

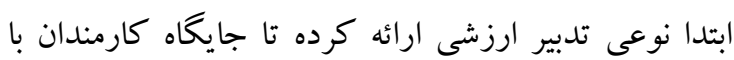
يكك سلسله افكار و ارزش هاى مشتر كك مشخّص كردد و از آن ها بخواهد وظائف خود را به روش اخلاقى انجام دهند(r). به عقيده يونوو تناكون (F)، رهبر اخلاقى، فردى است كه نه در جستجوى اجراى منافع شخصى خود به بهاى فدا كردن منافع ديخران بلكه به فكر منافع گروهى باشد و و همجنين كارمندانش را در تصميم گيرى درون سازمان 


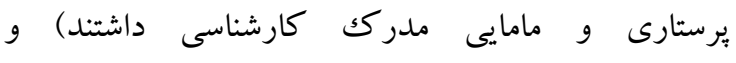
•هدرصدكار كنان (rا نفر) انتخاب شده اند كه از اعضاى كائ

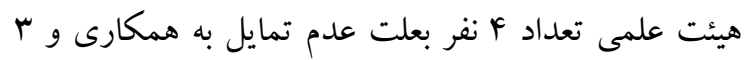

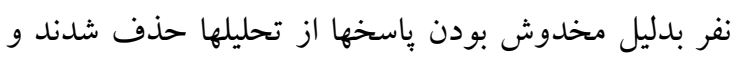

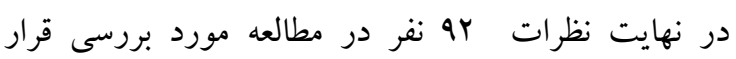

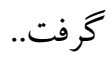
براى گردآورى داده ها در اين إثوهش از دو يرسشنامه

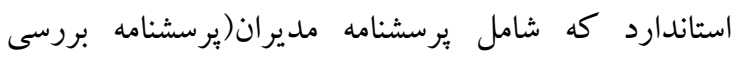

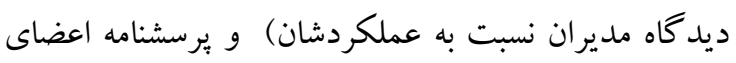
هيئت علمى و كار كنان آموزشى بود(براى هر دو از يكك

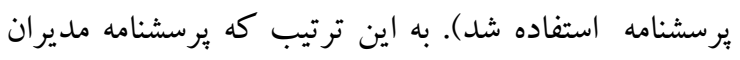

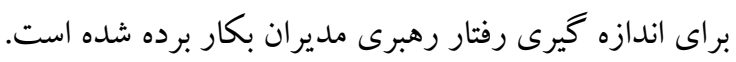

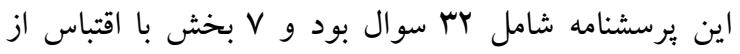

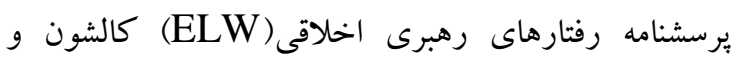

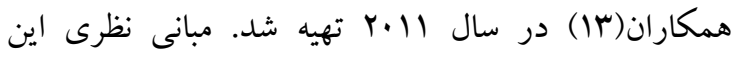

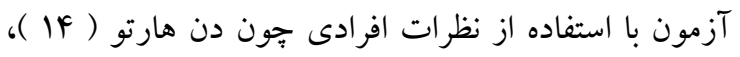

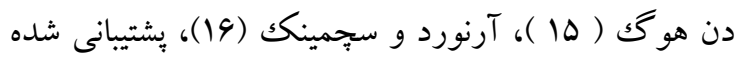
است. يرسشنامه رفتارهاى رهبرى اخلاقى مربوط به اعضاى هيئت علمى نيز داراى F مولفه، MF سوال با اقتباس از مقاله

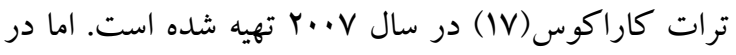
فر آيند تعيين روايى سوالات • او و وس حذف شده اند(هرجند يرسشنامه ها استاندارد بودند ولى براى اطمينان بيشتر از نظر روايى در اختيار اساتيد مرتبط با مديريت آموزشى دانشكاه

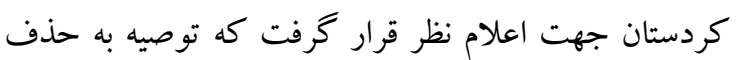

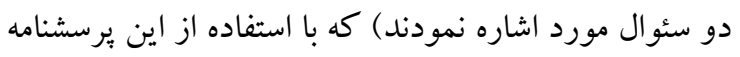
نحوه نغرش مدرسين (اعضاى هيئت علمى) درباره رعايت

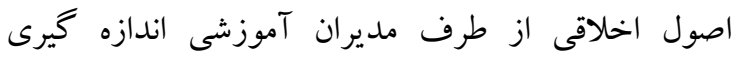
كرديد. هر جِند بِرسشنامه ها استاندارد بودند ولى براى اطمينان بيشتر

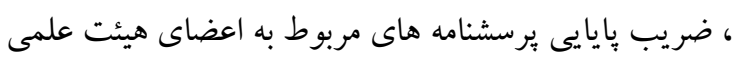

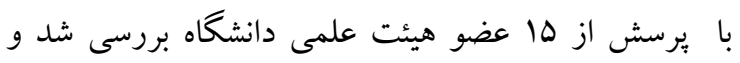

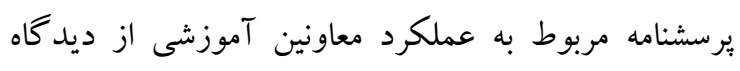
اعضاى هيئت علمى آلفاى كرانباخ محاسبه شده •9 / • بود و
نظريه نفع گرايى جمعى است كه ضرورت توجّه مديران به برخى اقدامات نظير طراحى منشور اخلاقى مناسب و نظام ياداش مناسب را نشان مى دهد. اين در حالى است كه نيرى

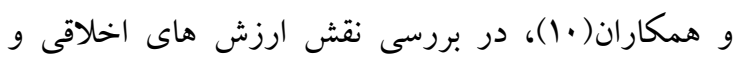

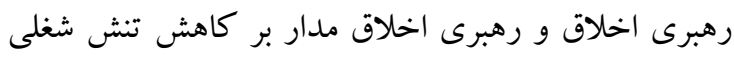

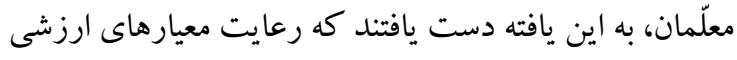

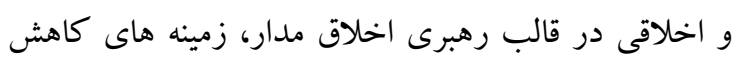
تنش شغلى را فراهم مى آورند.در مطالعه ای ديخر بين

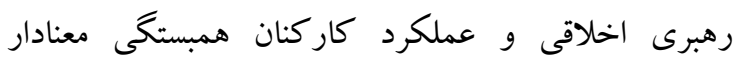

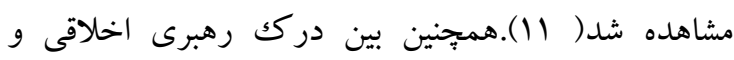

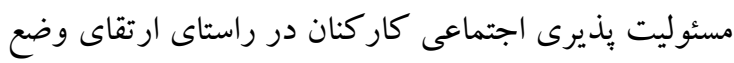
موجود نيز رابطه مشاهده شده است(Y (I). با توجه به اينكه در استان كردستان و بويزه در دانشكاه علوم يز شكى در اين زمينه تاكنون مطالعه اى انجام نشده است.اين مطالعه با هدف بررسى رهبرى اخلاقى در ميان مديران

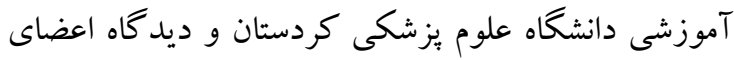
هيئت علمى در اين خصوص انجام شد.

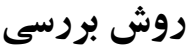
در اين مطالعه توصيفى- تحليلى جامعه آمارى مديران

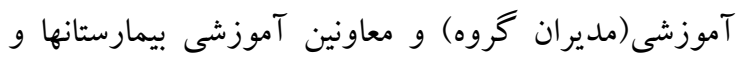
دانشكده ها، اعضاء هيأت علمى و كارشناسان(كاركنان)

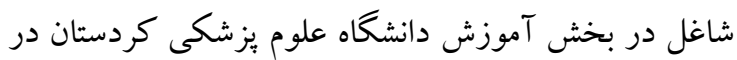
سال تحصيلى Q\$-q4 بودند. كه در بخش هاى مختلف

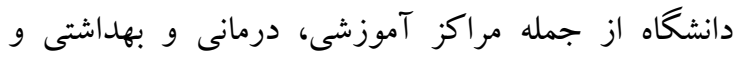
دانشكده ها، فعاليت آموزشى داشتند و تعداد آنها TV9 نفر بود.كه تعداد rه نفر از آن ها مديران آموزشى و 191 نفر اعضاء هيأت علمى و צr نفر كار كنان آموزشى(كارشناسان شاغل در بخشهاى آموزشى دانشكده ها و بيمارستانها) بودند. كه با استفاده از روش نمونه گيرى تصادفى ساده تعداد צY نفر ( •هدرصد مديران آموزشى (معاونين و مديران كروهها)) و 99 نفر ( •هدرصد اعضاء هيأت علمى،لازم به ماديه يادآوريست كه F نفر از اعضاى هيئت علمى دانشكده 
يرسشنامه ها در اختيار مديران و اعضاى هيئت علمى و

كار كنان آموزشى قرار كرفت و بعد از تكميل آنها مجددا از

$$
\text { آنها اخذ كرديد. }
$$

براى مديران آموزشى 9F/· بدست آمد. جِكونكى سنجش حيطه هاى اخلاق در مديريت در جداول ا وب ارائه شده اند.لازم به توضيح است كه ضمن يادآورى اهداف مطالعه،

جدول ا.انطباق مؤلفه هاى برسشنامه مديران آموزشى با هر يكك از سؤالات

\begin{tabular}{|c|c|c|c|c|}
\hline حداكثر نمره & حداقل نمره & شماره گويه & تعداد گويه & \\
\hline ro & $\Delta$ & $\Delta-r-r-r-1$ & $\Delta$ & جهت گيرى مردمى \\
\hline ro & $\Delta$ & $1 \cdot-9-\Lambda-V-9$ & $\Delta$ & 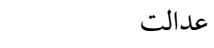 \\
\hline ro & $\Delta$ & $|0-| f-|r-| r-1 \mid$ & $\Delta$ & تسهيم قدرت \\
\hline 1. & r & $1 V-19$ & r & ثبات سازمانى \\
\hline$r$. & 9 & $r r-r Y-r \mid-r \cdot-19-11$ & 9 & رهنمودهاى اخلاقى \\
\hline$r$. & F & $Y V-Y G-Y \Delta-Y F$ & F & وضوح نقش \\
\hline ro & $\Delta$ & $r Y-r I-r \cdot-r q-r \Lambda$ & $\Delta$ & صداقت \\
\hline
\end{tabular}

جدول r.انطباق مؤلفه هاى برسشنامه اعضاء هيأت علمى با هريكك از سؤالات

\begin{tabular}{|c|c|c|c|c|c|}
\hline حداكثر نمره & & حداقل نمره & شماره كويه & تعداد كويه & \\
\hline & $\Delta \Delta$ & 11 & $11-1 \cdot-9-\Lambda-V-9-\Delta-r-r-r-1$ & 11 & اصول اخلاقى \\
\hline & $\Delta$. & 1. & $r \mid-r \cdot-19-11-1 V-19-10-1 F-1 Y-1 Y$ & 1. & جوّ اخلاقى \\
\hline & r. & 4 & $Y V-Y G-Y \Delta-Y F-Y Y-Y Y$ & 4 & اخلاق در تصميم كيرى \\
\hline & ro & $\Delta$ & $M r-r Y-r \mid-1-r \cdot-r 9-Y \wedge$ & $\Delta$ & فتنار اخلاقي \\
\hline
\end{tabular}

براى تحليل داده ها با توجه به نرمال بودن توزيع داده هاى كمى(بر اساس آزمون كولموكراف اسميرونوف) از آزمون t.test و براى متغيرهاى رتبه ای از كراسكال واليس استفاده شد.

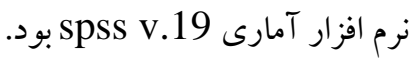


مورد مطالعه در جدول ب ارائه شده است.نتايج مربوط به حيطه هاى وضعيت رهبرى اخلاقى از ديد كاه اعضاى هيئت علمى و كار كنان آموزشى نشان داد كه و99/Yدرصد از مدير ان اصول اخلاقى رادر تصميم گيريها رعايت مى

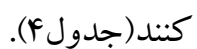

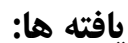

يافته هاى مربوط به اعضاى هيئت علمى و كار كنان

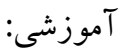

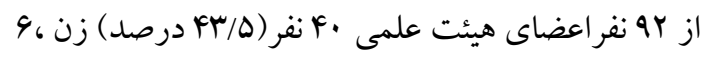
نفر (ه/ ودرصد) تحصيلات ليسانس، 91 نفر (49/Tد درصد) متخصص بودند. ميانخين سابقه كار بr/Y حداقل ا تا حداكثر ب سال بود.وضعيت مرتبه علمى گروه جدول ب.توزيع فراوانى مرتبه علمى

\begin{tabular}{|c|c|c|}
\hline درصد & فراوانى (نفر) & مرتبه هيئت علمى \\
\hline $99 / \pi$ & 91 & استاديار \\
\hline $9 / 1$ & 9 & دانشيار \\
\hline $19 / 9$ & 11 & 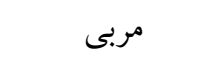 \\
\hline$r / r$ & f & كارشناس \\
\hline
\end{tabular}

جدول F. وضعيت رهبرى اخلاقى مديران آموزشى از ديد كاه اعضاى هيئت علمى و كار كنان آموزشى

\begin{tabular}{|c|c|c|c|c|}
\hline انحر اف معيار & ميانگين & (درصد) & (درصد) & حيطه ها \\
\hline$I V / \Delta Q$ & $99 / \Gamma 1$ & $Q F / \Delta D$ & MY/V & اصول اخلاقى \\
\hline $19 / A V$ & $V \cdot 19 \mathrm{~V}$ & $99 / .$. & $r F /$. & جو اخلاقى \\
\hline$I V / I D$ & $99 / 1$. & $9 \Lambda / \cdot \cdot$ & $r \cdot / \cdot$ & اخلاق در تصميم گيرى \\
\hline$|N / \mu|$ & $V r / \Lambda 9$ & $1 \cdots / \cdots$ & r/r & رفتار اخلاقى \\
\hline
\end{tabular}

تصميم گيرى رابطه معنادار بوده و كارشناسان به اين حيطه

امتياز بيشترى داده اند(جدول9).همجنين نتايج اين مطالعه

مشخص نمود كه ديد كاه اعضاى هيئت علمى و كار كنان آموزشى زن و مرد در هيجِكدام از حيطه ها تفاوت معنادارى

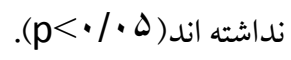

در خصوص رابطه سطح تحصيلات با رعايت حيطه هاى

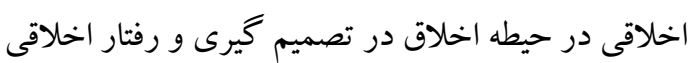

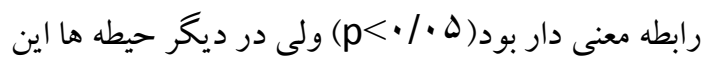
ارتباط مشاهده نشد(جدوله).بررسى رابطه مرتبه علمى با حيطه هاى اخلاقى نشان داد كه تنها در حيطه اخلاق در 
جدول ه. رابطه سطح تحصيلات با رعايت حيطه هاى اخلاقى(اعضاى هيئت علمى)

\begin{tabular}{|c|c|c|c|c|c|}
\hline$P$ & $x^{2}$ & ميانگين (رتبه اى) & فراوانى (نفر) & تحصيلات & حيطه \\
\hline \multirow{4}{*}{.$/ .1 f$} & \multirow{4}{*}{1.194} & $q V / V D$ & f & ليسانس & \multirow{4}{*}{ تصميم گيرى اخلاق در } \\
\hline & & Tr/Tr & 11 & فوق ليسانس & \\
\hline & & $\mathrm{FV} / \cdot 1$ & 94 & دكتراى تخصصى & \\
\hline & & $\Delta Q / \Delta F$ & v & فوق تخصص & \\
\hline \multirow{4}{*}{.$/ \cdot 1 \mathrm{~V}$} & \multirow{4}{*}{$1 . / 11$} & $V I / F r$ & f & ليسانس & \multirow{4}{*}{ رفتار اخلاقى } \\
\hline & & $r \Delta / l f$ & 11 & فوق ليسانس & \\
\hline & & $F \Delta / 94$ & $9 \pi$ & دكتراى تخصصى & \\
\hline & & $\Delta 9 / \Gamma q$ & $\checkmark$ & فوق تخصص & \\
\hline
\end{tabular}

جدول 9. رابطه مر تبه علمى با حيطه هاى اخلاقى (اعضاى هيئت علمى)

\begin{tabular}{|c|c|c|c|c|c|}
\hline$P$ & $x^{2}$ & ميانگين & فراوانى & مر تبه علمى & حيطه \\
\hline & & FV/Dr & 91 & استاديار & \\
\hline \multirow[t]{2}{*}{$\cdot / \cdot 4 \Lambda$} & $\mathrm{V} / \mathrm{M}$ & $r \Delta / .9$ & 9 & دانشيار & \\
\hline & & $\Delta Y / T H$ & M & مربى & تصميم گيرى \\
\hline
\end{tabular}

يافته ها نشان داد در خصوص حيطه هـاى مـديريت اخـلاق

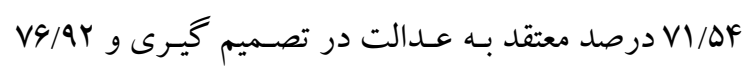
درصد معتقد بـه صـداقت در تصـميم گيـرى بودنـد(جـدول

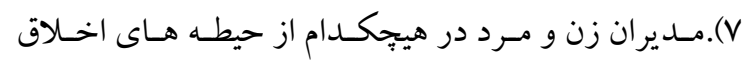

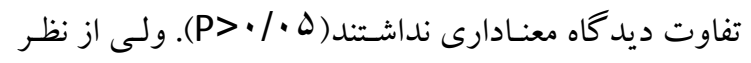
مقايسه ديد كاه مديران گروه و معاونتهاى آموزشى در حيطه هاى جهت گيرى، تسهيم قـدرت و رهنمودهـاى اخلاقى بـا

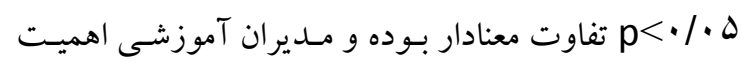

يافته هـاى مربـوط بـه مـديران آموزشسى(معـاونين و مــديران

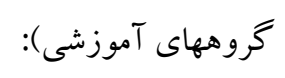

در اين بخش ديد گاه \& مدير آموزشى مـورد بررسى قرار

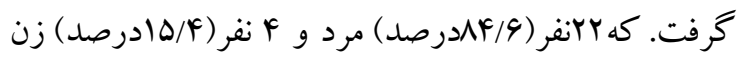

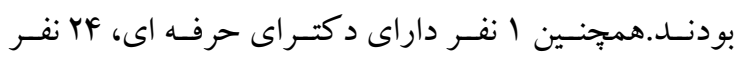

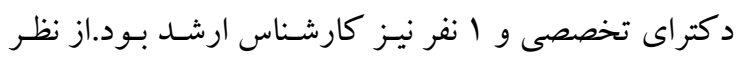

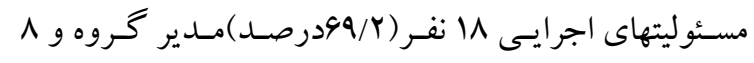
نفر (^/·rدرصد) معاون آموزشى بودند. 


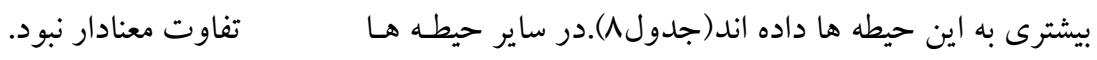
جدول V.ميانگين و انحراف معيار باور مديران و معاونتهاى آموزشى به حيطه هاى مديريت اخلاقى

\begin{tabular}{|c|c|c|c|c|}
\hline \multicolumn{5}{|c|}{$n=26$} \\
\hline انحراف معيار & ميانگين & حداكثر & حداقل & حيطه \\
\hline ( درصد) & ( درصد) & ( درصد) & ( درصد) & \\
\hline D & $V \Delta / Y \Lambda$ & $1 \cdots 1$ & $\Delta \cdot /$ & جهت گيرى \\
\hline$Q / 4 \wedge$ & $V I / \Delta F$ & $M / \cdot$ & $\Delta Y / \cdot$ & عدالت \\
\hline $11 / 49$ & $\sqrt{ } 9 / 99$ & $1 \cdots /$ & $\Delta r / \cdot$ & تسهيم قدرت \\
\hline$N / \Delta Y$ & $V M / \Lambda F$ & $9 \cdot / \cdot$ & $0 . \%$ & ثبات زمانى \\
\hline $1 \cdot / F F$ & WV/Vr & $99 /$. & $\Delta r /$ & ى اخلاقى \\
\hline $\mid Y / 1 \Lambda$ & $V / \Delta$. & $1 \cdots 1$ & $\Delta r /$. & \\
\hline $9 / 91$ & $V 9 / 9 Y$ & $1 \cdots$ & $\Delta \cdot \%$ & صداقت \\
\hline
\end{tabular}

جدول ^مرابطه برخى حيطه هاى مديريت اخلاقى با موقعيت شغلى مديران

\begin{tabular}{|c|c|c|c|c|c|c|}
\hline \multicolumn{7}{|c|}{$n=26$} \\
\hline$P$ & $\mathrm{~T}$ & انحراف معيار & ميانكين & فراوانى(نفر ) & & حيطه ها \\
\hline & & $r / V$. & $19 / F F$ & 11 & مدير گروه & \\
\hline$\cdot / \cdot F r$ & $r / 9 \Lambda$ & $1 / \mathrm{VV}$ & $1 \mathrm{~V} / \mathrm{D}$ & $\wedge$ & معاونت آموزشى & جهت كيرى \\
\hline & & $Y / 9 V$ & $Y F / \cdot \Delta$ & 11 & مدير گروه & رهنمودهاى اخلاقى \\
\hline$\cdot 1 \cdot 4 q$ & $r / \mu q$ & Y/VY & YI/GY & $\wedge$ & معاونت آموزشى & \\
\hline & & $Y / 9 V$ & $r \cdot / \Delta \Delta$ & 11 & مدير گروه & \\
\hline$\cdot / \cdot \Delta$ & $r / I V$ & $r / \cdots$ & $1 \wedge / \Delta$ & $\wedge$ & معاونت آموزشى & تسهيم قدرت \\
\hline
\end{tabular}

آن توسط مديران بوده اند. در اين خصوص با جستجوى

اينترنتى در بانكهاى اطلاعاتى داخلى و خارجى مطالعه ايى كه دقيقا اين عنوان و شاخصها را بررسى كرده باشد يافت نشد تا نتايج آنها با يافته هاى اين مطالعه مقايسه و مورد بحث قرار گيرد و عمدتا تاثير مديريت اخلاقى را بر عملكرد كارمندان سازمانها مورد مطالعه قرار داده اند كه بشكلى ميتواند با نتايج اين مطالعه نيز مرتبط باشد و بر اساس نتايج نتايج مطالعه حاضر نشان داد كه در كل در خصوص اخلاق در مديريت، اعضاى هيئت علمى ديد گاه مثبتى به مديران آموزشى دارند. بطوريكه در رعايت اصول اخلاقى؛ 99/Y1 درصد، جو اخلاقى 19V·V درصد، اخلاق در تصميم گيرى

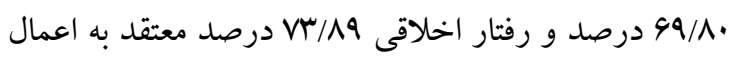
همله علمى دانشكاه علوه يِشكى كردستان / دوره بيست و سوه / ذرداد و تير Iس 
سازمان بسيار مهم و ضرورى است. انسجام و هماهنگى سازمان ارتباط زيادى با رهبرى اخلاقى دارد، جر اكه رهبرى اخلاقى واكنش هاى مثبت و مؤثرترى را نسبت به كارمندان از جمله درك كارآمدى و اطمينان او از متغيّرهاى مهم ديخر مانند رضايت از كار را در بر مى گيرد.و(جردن و

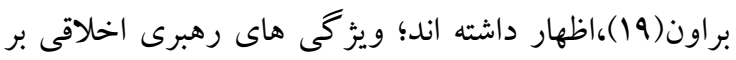
مر اقبت، اعتماد، صداقت و انصاف تكيه دارد. ديخر نتايج اين مطالعه نشان داد بين ديدگاه اعضاى هيئت علمى زن و مرد در خصوص حيطه هاى اخلاقى تفاوتى

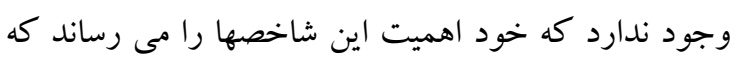

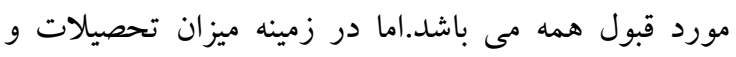

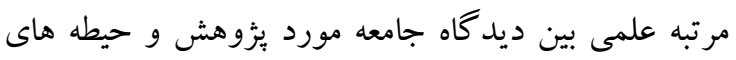

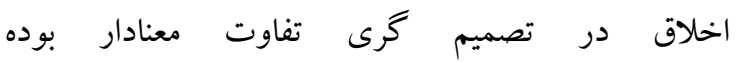

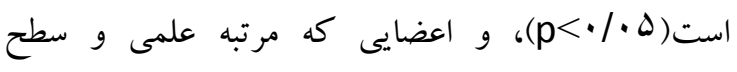
تحصيلات بيشترى داشته اند داراى نخرش مثبت ترى بوده

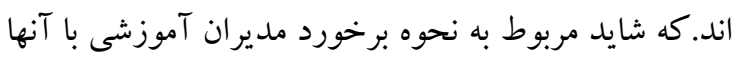
بدليل جايخاه علمى آنان بوده باشد.

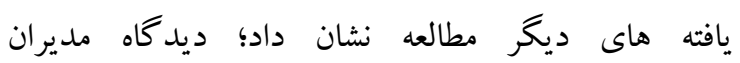

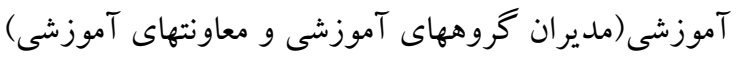
در خصوص اهميت حيطه هاى اخلاقى در كل مناسب بوده

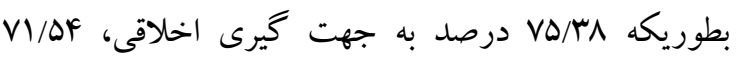
درصد به عدالت در تصميم گيرى، ديخران در قدرت و VY/AF درصد به ثبات زمانى باور داشته

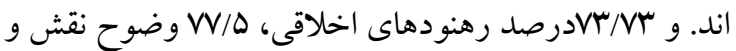

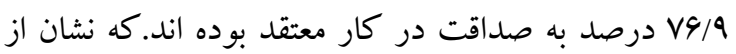
اهميت بالاى مديريت اخلاقى از ديد كاه جامعه مورد مطالعه است. اين در حاليست كه مطالعات نشان داده ؛ رعايت

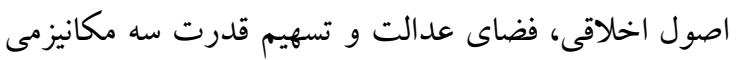
هستند كه رهبرى اخلاقى از طريق آن يادگيرى گروهى را بهبود مى بخشد(·r). در اين خصوص يونو و تناكون(F)، تحقيقى را در كشور مالزى با عنوان ارابطه ى بين رهبرى

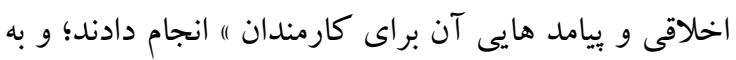

آنها براى مطالعه حاضر نتيجه گيرى كردكه بعنوان يك محدوديت ميتواند مطرح باشد. در اين رابطه عمادى فر(م)، با انجام يزوهشى تحت عنوان بررسى سبك رهبرى اخلاقى

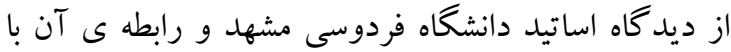
توانمند سازى آنان، به اين نتيجه رسيد كه نمره ى سبك رهبرى اخلاقى مديران جامعه مورد نظر با متوسط نمره شركت كنند كان تقريباً برابر است. كه در مقايسه با يافته هاى ما همخوانى دارد زيرا در مطالعه حاضر نيز ديدكاه اعضاى هيئت علمى و مديران آموزشى در خصوص رعايت فضاى اخلاقى در محيط كارى بهم نزديكك است و هر دو كروه ديد مثبى به حيطه هاى مختلف اخلاقى داشته اند. همجنين الوانى و همكاران(9)، در تحقيقى با عنوان تحليل اخلاقى سازمانى كار كنان با استفاده از الكوى دايره اخلاق، به اين نتيجه رسيدند كه گرايش كاركنان دانشگاه به نظريه نفع گرايى جمعى است كه ضرورت توجّه مديران به برخى اقدامات نظير طراحى منشور اخلاقى مناسب و نظام باداش مناسب را نشان مى دهد. اين در حالى است كه نيرى و همكاران( • ()، در بررسى نقش ارزش هاى اخلاقى و رهبرى اخلاق و رهبرى اخلاق مدار بر كاهش تنش شغلى معلّمان، به اين يافته دست يافتند كه رعايت معيارهاى ارزشى و اخلاقى در قالب رهبرى اخلاق مدار، زمينه هاى كاهش

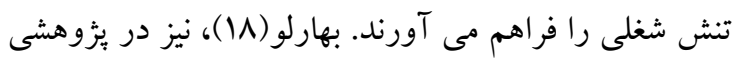
با عنوان (اتحليل رابطه رهبرى اخلاقى و رفتار شهروندى سازمانى" به اين نتيجه دست يافت كه به كاركيرى سبك رهي رهبرى اخلاقى با انجام رفتارهاى فرا نقش كار كنان ارتباط دارد. بنابراين سازمان ها مى توانند با به كار گيرى اين سبكك

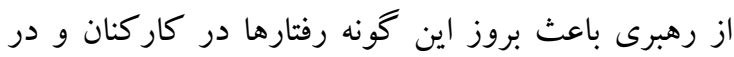
نتيجه افزايش بهره ورى سازمان شوند. برخى صاحبنران عرصه مديريت از جمله؛استنماركك و ميو مفورد(4)اظهار داشته اند؛ رهبرى اخلاقى در يكك سازمان، براى موفقيّت آن 
به اين حيطه ها توجه بيشترى داشته اند.اين تفاوت ممكن

است ناشى از هم سطح بودن اعضاى گروهها از نظر

تحصيلات و مرتبه علمى باشد كه فضاى اخلاقى بهترى را

براى همكاران گروه فراهم نموده است.دين هن زنغك و

همكاران(Yץ)، در مطالعه اى به اين نتيجه رسيدند كه رهبرى

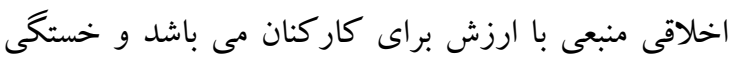

عاطفى ييروان را كاهش مى دهد. والومبا و همكاران(Yه)،

نيز به اين نتيجه رسيدند كه رهبران اخلاقى سرمشقى براى

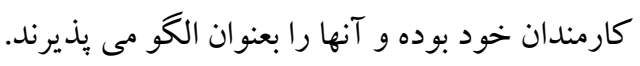

\section{نتيجه كيرى}

نتايج مطالعه حاضر نشان داد هرجند از ديدكاه مديران

آموزشى و اعضاى هيئت علمى در حيطه هاى مديريت

اخلاقى وضعيت دانشكاه نسبتا مناسب است ولى تاثير اين

وضعيت بر راندمان كارى و ساير متغيرهاى ارتباطى مشخص

نيست كه انجام مطالعات بيشترى در اين راستا توصيه ميشود.

\section{تشكر و قدرانى}

نويسندكان از تمامى مديران آموزشى و اعضاى هيت علمى

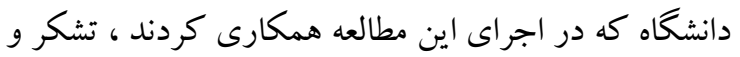

$$
\text { قدردانى مى نمايند. }
$$

اين نتيجه رسيدند كه رفتار رهبرى اخلاقى ارتباط زيادى با تعهد سازمانى كارمندان و اعتماد به رهبران دارد. كالشوون و همكاران(r|)، تحقيقى تحت عنوان (ارهبرى اخلاقى و توسعه معيارهاى جند بعدى" به اين نتيجه رسيدند كه رهبرى

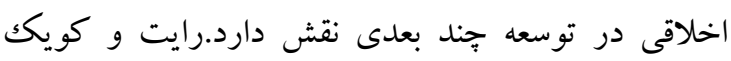
(Y) اخلاقى" انجام دادند؛ نتايج نشان داد كه ابعاد اخلاقى لتحنى

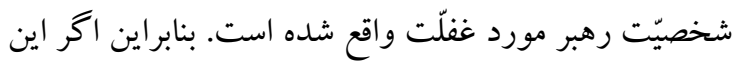
ابعاد به وسيله ى تحقيقات تجربى حمايت شوند، مى تواند در شناخت ما براى انتخاب رهبرى مبتى بر شخصيّت مهم

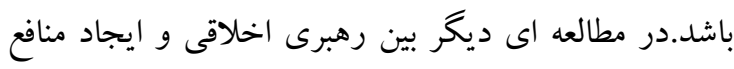
بيشتر براى سازمان رابطه تاييد شده است(YY). آنجلا شين لين

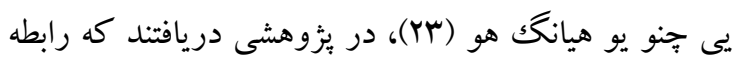
ى مثبت بين رهبرى اخلاقى و خلاقيّت كارمند از طريق

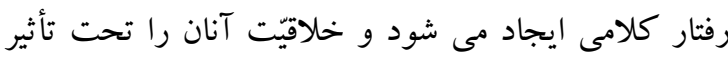
قرار مى دهد. ديخر نتايج مطالعه حاضر نشان داد كه مديران زن ون و مرد ديدكاهشان در خصوص مديريت اخلاقى تفاوت معنادار

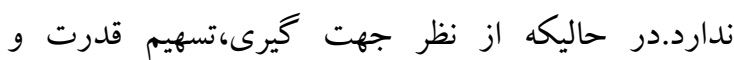

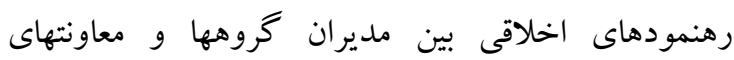

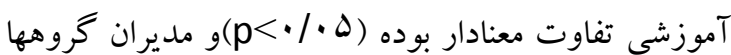

\section{References}

1. Stouten J, Van Dijke M, Mayer DM, De Cremer D, Euwema MC. Can a leader be seen as too ethical? The curvilinear effects of ethical leadership. Leadersh Q 2013; 24: 680-95.

2. Starratt RJ. Bulding an ethical school: a theory for Practice in educational Leadership. Educ Adm Q 1991; 27: 66-75.

3. Sanjari AR. The art of management and ethical leadership in educational organizations. J Tadbir 1996; 69: 28-31. [In Persian]

4. Ponnu HC, Tennakoon G. The association between ethical leadership and employee outcomes the malaysian case. EJBO 2009; 14: 21-30.

5. Golparvar M, Padsha F, Atashpour H. Reinforcing model of feeling of energy, empowerment and creativity of teachers through ethical leadership. IOH 2010; 63: 4-11. [In Persian]

6. Stenmark KC, Mumford DM. Situational Impacts on Leader Ethical decision-making. Leadership Q 2011; 22: 942-55.

7. Brown EM, Trevino KL. Ethical Leadership: A Review and Future Directions. Leadership Q 2006; 17: 595-616. 
8. Emadi far A. Check moral leadership from the perspective of teachers Ferdowsi University of Mashhad and its relation to their empowerment [dissertation]. Mashhad: Ferdowsi University of Mashhad; 2010. [In Persian]

9. Alvany M, Hassan Pour A, Davari A. Analysis of organizational ethics with morality circular pattern. Journal of Ethics in Science and Technology 2011; 4: 25-34. [In Persian]

10. Neary SH, Golparvar M, Mahdad A. The role of moral values and moral leadership in reducing job stress. Ethics in Science and Technology Quarterly 2010; 4: 67-76. [In Persian]

11. Rezaei HR, Fadaei M, Ebrahimi P. The role of ethical leadership on employee performance in Guilan University of medical sciences. Procedia Soc Behav Sci 2016; 230: 463-70.

12. Akdogan A, Aykut A, Ozgur D. A Strategic Influence of Corporate Social Responsibility on Meaningful work and Organizational Identification, via Perceptions of Ethical Leadership. Procedia Soc Behav Sci 2016; 235: 259-68.

13. Kalshoven K, Den Hartog ND, De Hoogh BA. Ethical leadership at work questionnaire (ELW): development and validation of a multidimensional measure. Leadership Q 2011; 22: 51-69.

14. Den Hartog DN, De H. Empowerment and leader fairness and integrity: Studying ethical leader behavior: From a lavels-of-analysis perspective. EJWOP 2009; 18: 199-230.

15. De Hoogh AHB, Den Hartog DN. Ethical and despotic leadership, relationships with leader's social responsibility, top management team effectiveness and subordinates' optimism: A multi-method study. Leadership Q 2008; 19: 297-311.

16. Arnaud AU, Schminke M, editors. Beyond the organizational bases of ethical work climates: A new theory and measure. 66th annual meeting of the academy of management. 2006 Aug. 6, Atlanta, United States.

17. Karakose T. High school teachers' perceptions regarding principals' ethical leadership in Turkey. APER 2007; 23: 464-77.

18. Baharloo M, Balydh K, Neami AZ. Analysis of the relationship between ethical leadership and organizational citizenship behavior. Ethics in Science and Technology Quarterly 2015; 1: 19-27. [In Persian]

19. Jordan J, Brown ME, Trevino LK, Finkelstein S. Someone to look up to: Executivefollower ethical reasoning and perceptions of ethical leadership. J Manag 2013; 39: 660-82.

20. Fred O, Chad A, Everlyne M. Does ethical leadership enhance group learning behavior? Examining the mediating influence of group ethical conduct, justice climate, and peer justice. J Bus Res 2017; 72: 14-23.

21. Wright AT, Quick CG. Role of character in ethical leadership research. Leadership Q 2011; 22: 975-8.

22. Wilson S, Mc Calman J. Re- imagining ethical leadership for the greater good. EMJ 2016; 37: $1-4$.

23. Chen, ASY, Hou YH. The effects of ethical leadership, voice behavior and climates for innovation on creativity: A moderated mediation examination. Leadership Q 2016; 27: 1-13.

24. Dianhan Z, La W, Eleanor W, Emily M, David MVD, Danial P, et al. Effects of ethical leadership on emotional exhaustion in high moral intensity situations. Leadership Q 2015; 26: 732-48.

25. Walumbwa FO, Morrison EW, Christensen AL. Ethical leadership and group in-role performance: The mediating roles of group conscientiousness and group voice. Leadership Q 2012; 23: 953-64. 